Abstract P-024 Table 1 Aneurysm Occlusion Rates

\begin{tabular}{|c|c|c|c|}
\hline Rate of Occlusion & Procedure $(n=100)$ & 3-9 Months $(n=66)$ & 9-18 Months ( $n=42)$ \\
\hline $\begin{array}{l}\text { Grade } 0 \text { : complete } \& \text { total } \\
\text { aneurysm occlusion }\end{array}$ & 33 & 40 & 24 \\
\hline $\begin{array}{l}\text { Grade } 1: \geq 90 \% \text { volumetric } \\
\text { aneurysm occlusion }\end{array}$ & 47 & 13 & 8 \\
\hline $\begin{array}{l}\text { Grade } 2: 70-89 \% \text { volumetric } \\
\text { aneurysm occlusion }\end{array}$ & 15 & 9 & 7 \\
\hline $\begin{array}{l}\text { Grade } 3: 50-69 \% \text { volumetric } \\
\text { aneurysm occlusion }\end{array}$ & 3 & 3 & 2 \\
\hline $\begin{array}{l}\text { Grade } 4: 25-49 \% \text { volumetric } \\
\text { aneurysm occlusion }\end{array}$ & 0 & 1 & 1 \\
\hline $\begin{array}{l}\text { Grade } 5 \text { : }<25 \% \text { volumetric } \\
\text { aneurysm occlusion }\end{array}$ & 2 & 0 & 0 \\
\hline \multicolumn{4}{|l|}{ Raymond ooclusion Scale } \\
\hline Complete & 45 & 42 & 26 \\
\hline Minimal Residual & 52 & 18 & 11 \\
\hline Residual Aneurysm & 3 & 6 & 5 \\
\hline
\end{tabular}

Microvention. C. Schirmer: 1; C; NIH/NINDS. 6; C; AANS Honoraria, Ownership- NTI. B. Pukenas: 1; C; Stryker Neurovascular. S. Satti: 2; C; Stryker Neurovascular, Penumbra, Cerenovus, Terumo. 6; C; Medtronic - Proctor. T. Miller: None. D. Gandhi: 1; C; Stryker Neurovascular.

\section{P-025 OUTCOME STUDY OF PIPELINE EMBOLISATION DEVICE WITH SHIELD TECHNOLOGY IN UNRUPTURED ANEURYSMS}

${ }^{1} \mathrm{~N}$ Kandasamy*, ${ }^{1} \mathrm{~T}$ Booth, 'J Hart, ${ }^{2} \mathrm{D}$ Atasoy, ${ }^{3} \mathrm{Y}$ Shih-hung. 'Neuroradiology, King's College hospital, London, UK; ${ }^{2}$ Neuroradiology, Karadeniz Technical University Farabi Hospital, Turkey; ${ }^{3}$ Neuroradiology, Taipei Medical University-Municipal Wan Fang Hospital, Taiwan

\subsection{6/neurintsurg-2019-SNIS.61}

Background Pipeline Flex Embolization Device with Shield Technology (Pipeline Shield) has recently been introduced as the third generation of Pipeline flow-diverter devices (FDDs) with a new stent surface modification giving reduced thrombogenicity.

Objective We aimed to evaluate clinical (safety) and radiographic (efficacy) outcomes of the Pipeline Shield.

Methods The 30 day and 1-year mortality and morbidity rates, and the 6 and 18 month radiographic aneurysm occlusion outcomes for procedures performed between March 2016 and January 2018, were reviewed. 3D-TOF-MRA was used for follow up.

Results A total of 44 attempted Pipeline Shield procedures were performed for 41 patients with 44 target aneurysms (total 52 aneurysms treated). $88.5 \%$ were inserted in the anterior circulation and $11.5 \%$ the posterior circulation. $49 / 52$ (94.2\%) aneurysms were saccular, 1/52 (1.9\%) was fusiform. One $(1.9 \%)$ aneurysm was an iatrogenic pseudoaneurysm and one (1.9\%) was a dissecting aneurysm. 71\% (35/49) of the saccular aneurysms were wide-necked (neck >4 mm), 34.6\% $(18 / 52)$ were large $(\geq 10 \mathrm{~mm})$ and $3.8 \%(2 / 52)$ were giant $(\geq 25 \mathrm{~mm})$. The mean aneurysm sac maximal diameter was
$9.2 \mathrm{~mm}$, and mean neck width was $5.1 \mathrm{~mm}$. The cumulative mortality and morbidity rates were $2.3 \%$ and $9.2 \%$ at 1 year, respectively. The adequate occlusion rate was $78.8 \%$ at 6 months and $90.3 \%$ at 18 months.

Conclusions In this pragmatic and independent study, the occlusion rates and safety outcomes were similar to those seen in previously published studies with FDDs and earlier generation PEDs.

Disclosures N. Kandasamy: 6; C; contribution towards institutional study budget. T. Booth: 6; C; institutional study budget support. J. Hart: 6; C; Institutional study budget support. D. Atasoy: None. Y. Shih-hung: None.

\section{P-026 THE USE OF HIGH-FREQUENCY OPTICAL COHERENCE TOMOGRAPHY FOR FOLLOW-UP IMAGING OF TREATED ANEURYSMS}

R King*, M Marsofoi, E Langan, M Shazeeb, G Ughi, C Raskett, A Puri, M Gounis. Radiology, University of Massachusetts, Worcester, MA

\subsection{6/neurintsurg-2019-SNIS.62}

Introduction The use of flow diverters has emerged as an effective treatment of aneurysm. One of the major limitations of flow diverters is the need to put patients on dual anti-platelet therapy (DAPT). The exposure of bare metal struts leads to platelet activation. A method to assess the degree of neointimal tissue ingrowth over the surface of the device could permit patient-specific tailoring of DAPT. Currently, the standard of follow-up for flow diverter patients is digital subtraction angiography (DSA); however, it has been previously reported DSA appearance of complete aneurysm occlusion is not always reliable with continued aneurysm growth. ${ }^{1}$ There have been reported cases of very delayed complications after DAPT has been stopped, ${ }^{2}$ although rare, such complications can be catastrophic.

High Frequency Optical Coherence Tomography (HF-OCT) is a novel intravascular imaging technique designed for use in 